\title{
Relationship Between Uterine Development, mRNA and Protein Expression of FSH and LH Receptors in New Zealand White Rabbits
}

\author{
Eman Khalil*, Mohamed Metwally, Hatem Bahgat, Ahmed Kassab, Anwar El-Shafey \\ Department of Anatomy and Embryology, Faculty of Veterinary Medicine, Benha University, Moshtohor 13736, \\ Egypt.
}

\begin{abstract}
Gonadotropin receptors; follicle-stimulating hormone receptor (FSHR) and luteinizing hormone receptor (LHR), are well known for their indispensable function in female reproductive regulation. LHR and FSHR were previously thought to have only gonadal tissue expression, however it has recently been discovered that they are expressed in a range of extragonadal tissues. However, whether these receptors play a role in rabbit uterine development is uncertain. The objective of this study was to investigate the relationship between uterine development and mRNA and protein expression of FSHR and LHR in the New Zealand white rabbits. Uteri were collected from thirty New Zealand rabbits at Day 0, week (W) 2, W4, W16, and Day18 of pregnancy ( $\mathrm{n}=6$ /group), and ovarian histology, gene as well as protein expression were investigated using light microscopy, real-time PCR and Western blot, respectively. The findings revealed that uterus was not yet differentiated into its definite three layers, and there was no evidence of glandular development at birth. Primordium of uterine gland formation was first observed at W 2. By W16, extensive tubular glands underwent branching and coiling within the stroma. At pregnancy, endometrial glands became abundant. No significant changes in FSHR and LHR mRNA and protein expression were detected from birth to W16 which was not compatible with the linear increase of histological features of the rabbit uterus during developmental stages. However, the mRNA and protein for these receptors during pregnancy were significantly $(\mathrm{p}<0.05)$ increased. In conclusion, there was no relation between rabbit uterine developmental changes and FSHR and LHR expression, suggesting that these receptors are not involved in regulating rabbit uterine development and that uterine development is controlled by other factors.
\end{abstract}

Keywords | Gonadotropin receptors, Uterine adenogenesis, Western blot, qRT-PCR

Received | September 06, 2021; Accepted | October 24, 2021; Published | December 01, 2021

*Correspondence | Eman K. Khalil, Department of Anatomy and Embryology, Faculty of Veterinary Medicine, Benha University, Moshtohor 13736, Egypt; Email: emankama121391@gmail.com

Citation | Khalil E, Metwally M, Bahgat H, Kassab A, El-Shafey A (2022). Relationship between uterine development, mRNA and protein expression of FSH and LH receptors in New Zealand white rabbits. Adv. Anim. Vet. Sci. 10(1): 139-144.

DOI | http://dx.doi.org/10.17582/journal.aavs/2022/10.1.139.144

ISSN (Online) | 2307-8316; ISSN (Print) | 2309-3331

Copyright (C) 2022 Khalil et al. This is an open access article distributed under the Creative Commons Attribution License, which permits unrestricted use, distribution, and reproduction in any medium, provided the original work is properly cited.

\section{INTRODUCTION}

$\mathrm{T}$ he female rabbit possesses a bicornuate duplex uterus. This type of uterus has two separate uterine horns ended by two united services and the two cervices open into a single vagina (Abd-Elkareem, 2017). Although most female reproductive organs have completed organogenetic differentiation and development at birth, the uterus is not completely differentiated at birth (Spencer et al., 2005). Postnatal uterine development is marked by some morphogenetic events which include differentiation of endometrial stroma; endometrial gland development, and myometrium differentiation (Gray et al., 2001). Even though the uterus is critical for female fertility, the cell, hormonal and molecular pathways that regulate uterine development are less understood (Hu et al., 2004).

The interactions of FSH and $\mathrm{LH}$ with their receptors is a critical step in the regulation of mammalian gonadal function and female reproductive development (Dias et al., 2002). The mutations of FSHR and LHR lead to female reproductive dysfunction (Costagliola et al., 2005). These 
receptors are a member of the $\mathrm{G}$ protein-coupled receptor family, which has seven transmembrane domains (Ascoli et al., 2002; Narayan et al., 2018). LHR and FSHR were previously thought to have only gonadal tissue expression. However, there is cumulative evidence that these receptors can be found in the female extragonadal tissue. Indeed, gonadotropins receptors have been identified in the uterus of many species including ovine (Wang et al., 2012), rabbits and rats (Sawitzke and Odell, 1991), humans (Sacchi et al. 2018), mice (Zheng et al., 2001; Wei et al., 2016) and porcine (Liang et al., 2012). Although the expression of FSHR and LHR was detected in these animals, little information is provided concerning the postnatal uterine development pattern in New Zealand white rabbits and their relationship with FSHR and LHR expression. Therefore, this study aimed to investigate the rabbit uterine histological changes and their relationship with expression patterns of LHR and FSHR at mRNA and protein levels from birth to maturity and during pregnancy, which would help to broaden our knowledge of the expression of both gonadotropin receptors in extragonadal tissues that may contribute to the improvement of rabbit reproduction.

\section{MATERIALS AND METHODS}

\section{Tissue SAMPLES COLLECTION}

Thirty healthy female New Zealand white rabbits were collected from the animal house at Benha University's Faculty of Veterinary Medicine. The animals were housed in individual cages with controlled temperature $\left(23 \pm 2^{\circ} \mathrm{C}\right)$ under a 12:12h light: dark cycle and provided with free access to water and food. The rabbits were euthanized by decapitation according to the guidelines of the animal care committee of the Faculty of Veterinary Medicine, Benha University (ethical approval number: BUFVTM 08-3-21). Uteri of female rabbits aged 0 day, 2, 4, 16 weeks and uteri from pregnant rabbits (18-days postcoitum, 18dpc) ( $\mathrm{n}=6 /$ group) were taken immediately after euthanasia. The right uterine horn was kept at $-80^{\circ} \mathrm{C}$ until protein and RNA extraction, while the left uterine horn was collected for the histological examination in Bouin's fluid for 24 hours.

\section{Histological preparation}

The samples were washed in a phosphate buffer after fixation, then dehydrated through a graded ethanol series and blocked in paraffin wax. On gelatin-coated slides, 5 $\mu \mathrm{m}$ sections were mounted, stained with hematoxylin and eosin stain (Feldman and Wolfe, 2014).

\section{Quantitative REAL-TIME PCR}

Total RNA Purification Kit was used to extract total RNA from uterine tissues following the manufacturer protocol (iNtRON Biotechnology, easy-REDTM Total RNA Extraction Kit) as previously described (Abd-Allah et al., 2015). cDNA was synthesized from $5 \mu \mathrm{g}$ of total RNA using M-MuLV Reverse Transcriptase enzyme following the manufacture's protocol (Thermo Scientific, Fermentas, \#EP0451). Quantitative PCR assays were conducted using 2X Maxima SYBR Green/ROX qPCR Master Mix according to the manufacturer's instructions (Thermo Scientific, USA, \# K0221). The PCR cycling conditions were as follows: $95^{\circ} \mathrm{C}$ for $10 \mathrm{~min}, 40$ cycles of $95^{\circ} \mathrm{C}$ for 15 sec and $60^{\circ} \mathrm{C}$ for $1 \mathrm{~min}$. The melting curve was produced by increasing temperature from 60 to $95^{\circ} \mathrm{C}$. The primers sequences were shown in (Table 1). For each gene, the relative mRNA expression level was determined using the delta-delta Ct method (Livak and Schmittgen, 2001). The results were shown as relative values compared to $G A P D H$ expression (internal control).

\section{WESTERN BLOT}

Western blot was performed to assess the protein expression of FSHR and LHR in the rabbit uteri. The uterine samples were homogenized in RIPA buffer as reported previously (Yang et al., 2004). A total of $20 \mu \mathrm{g}$ cytosolic proteins were loaded and run on 5-12\% SDS-polyacrylamide gel (SDSPAGE) then gels were electrotransferred to polyvinylidene fluoride (PVDF) membranes (Bio-Rad, USA). The membrane was blocked with $3 \%$ bovine serum albumin in Tween-20 Tris buffered saline (TPST) for 1-2 $\mathrm{h}$ at room temperature. After blocking, the membranes were incubated with primary antibodies: anti- $\beta$-actin (1:1000, ab8226,Abcam), anti-FSHR(1:500, ab75200,Abcam), and anti-LHR (1:500, ab179780, Abcam). The membrane was washed and then incubated with horseradish peroxidaseconjugated goat anti-rabbit IgG secondary antibody which was diluted at 1:5000 in blocking solution for 1 hour at room temperature. The average optical density of positive bands was analyzed using Image J software. The density of each band was normalized to its respective loading control ( $\beta$-actin).

Table 1: Primer sequences for RT-PCR.

\begin{tabular}{|c|c|c|}
\hline Gene & $\begin{array}{l}\text { Forward primer } \\
\text { (/5 -----/3) }\end{array}$ & $\begin{array}{l}\text { Reverse primer } \\
(/ 5 \text {----- /3) }\end{array}$ \\
\hline FSHR & GAGGAATGCCATTGA ACTGAGG & AAGGTTGGAGAACACATCTG \\
\hline LHR & CTG GAG AAG ATG CAC AAT GG & AATTAGCCTCTGAATGGACTC \\
\hline GAPDH & TGTTTGTGATGGGCGTGAA & CCTCCACAATGCCGAAGT \\
\hline
\end{tabular}


STATISTICAL ANALYSIS

Both FSHR and LHR mRNA and protein expression were statistically analyzed by one-way analysis of variance (ANOVA) using SPSS, 16.0 software and the Duncan test was used as the post hoc test. All data were presented as mean \pm standard error of mean (SEM). P-value $<0.05$ was considered to be a significant difference.

\section{RESULTS AND DISCUSSION}

\section{Histological Results}

At birth, the uterus was not yet differentiated into its definite three layers, consisted mainly of a simple-topseudostratified columnar epithelium surrounded by undifferentiated mesenchyme, and lacked uterine glands (Figure 1A). Within 2 weeks after birth, the uterus differentiated into three separate layers and shallow epithelial invaginations appeared along the lamina epithelialis representing the primordium of uterine glands (the first stage of adenogenesis, bud formation). The muscular layer was an ill-defined layer and the developing smooth muscles were mainly of circular orientation (Figure 1B). The three layers became more prominent in the uterus of 4-weeks-old rabbit and the nacent glandular epithelial buds proliferated and extended radially into the underlying lamina propria forming tubular structures that gave a corrugated appearance to the luminal uterine epithelium (the second stage of adenogenesis, tubulogenesis). The Myometrium layer became more defined but still arranged in a circular manner (Figure 1C). At 16 weeks of age, the mature uterine histoarchitecture was observed. The lumen of the endometrium became narrower had a slitlike appearance due to the appearance of numerous welldeveloped endometrial folds (Figure 1D). Extensive tubular glands extended deeper in the endometrial stroma toward the inner circular muscles and underwent slight branching within the stroma and numerous glandular epithelium was present throughout the endometrial stroma (the third stage of adenogenesis, branching morphogenesis) (Figure $1 \mathrm{E})$. The myometrium layer became thicker and more differentiated into thin outer longitudinal layers and thick inner circular layers (Figure 1D).

During pregnancy, the uterine architecture including decidua parietalis underwent dramatic changes. The complexity of luminal folding and crypt formation was observed. The lamina propria of the endometrial folds was a thin connective tissue layer with an abundance of the uterine endometrial glands that have enlarged lumina (Figure 1F).

\section{FSHR AND LHR GENES EXPRESSION}

Real-time PCR analysis showed that the FSHR and LHR mRNA expression were not significantly different from birth to week 16. However, a significant increase in FSHR and LHR mRNA levels during pregnancy as compared to other developmental stages (Figure 2A, B).

\section{FSHR AND LHR PROTEINS EXPRESSION}

Western blotting analysis has been performed on FSHR and LHR proteins to validate their expression in the rabbit uterus. FSHR and LHR proteins were detected with a size of $78 \mathrm{kDa}$ and $72 \mathrm{kDa}$, respectively (Figure $3 \mathrm{~A})$. Both proteins did not show any significant difference from birth to maturity, but at pregnancy, their expression was significantly increased relative to other developmental stages (Figure 3B, C).

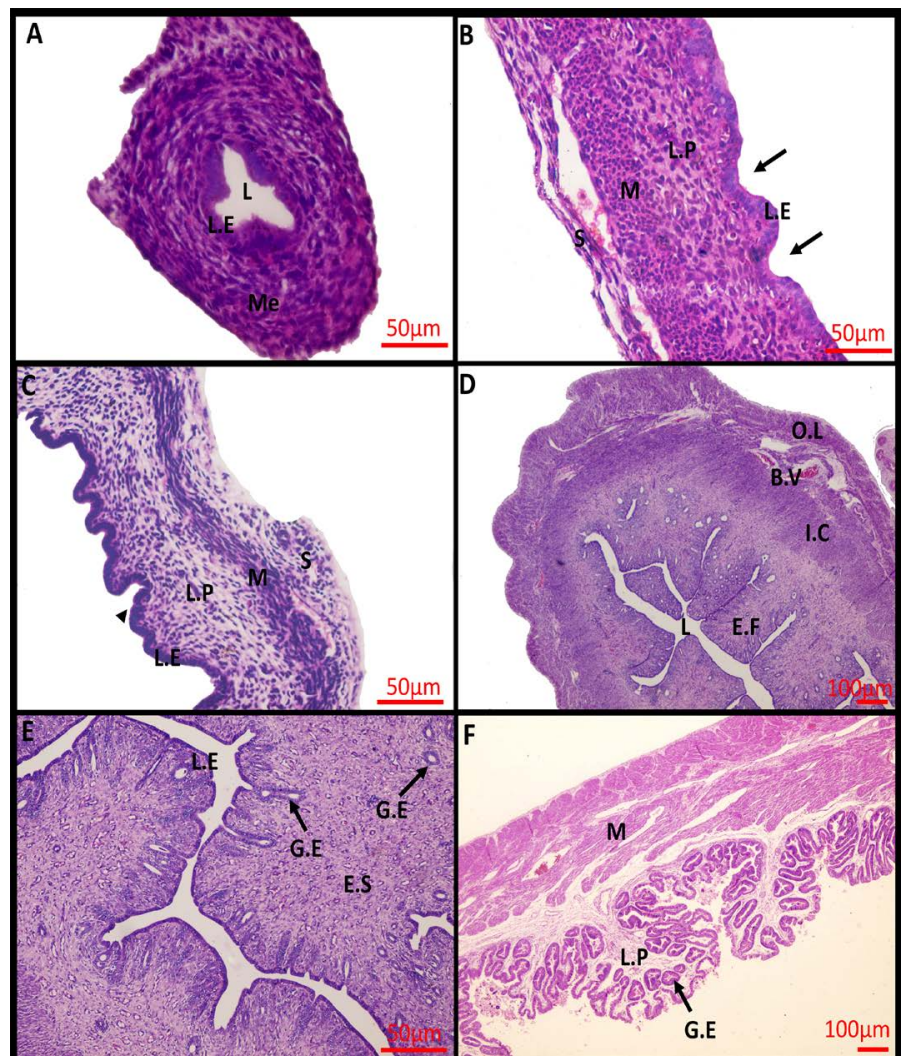

Figure 1: Photomicrograph of the rabbit uterus at various development stages. (A) 0day, (B) 2weeks, (C) 4weeks, (D, E) 16weeks, (F) 18 days' pregnant rabbit uterus. Me, mesenchymal layer; L, Lumen; L.E, Lamina epithelialis; M, Muscular layer; S, Serosa; L.P, Lamina Propria; Arrow: Shallow epithelial invaginations; Arrow head, Tubular structure; E.F, Endometrial folds; I.C, Inner circular layer; O.L, Outer longitudinal layer; B.V, Blood vessels; G.E, Glandular epithelialis; E.S, Endometrium stroma; Scale Bar: $50 \mu \mathrm{m}(\mathrm{A}, \mathrm{B}, \mathrm{C}, \mathrm{E}) ; 100 \mu \mathrm{m}(\mathrm{D}, \mathrm{F})$ (Hematoxylin and Eosin stain).

FSHR and LHR expressions were previously believed to be limited to gonadal tissue. However, recent researches have discovered that gonadotropin receptors are expressed in both gonadal and extragonadal reproductive organs (Mukherjee et al., 2010). Considering this, data on uterine FSHR and LHR expression profile in various animal species is very 
interesting. To our knowledge, our research was the first to relate changes in FSHR and LHR expression at the mRNA and protein levels to uterine histological changes in female rabbits using RT-PCR, western blot, and histological techniques. This study was carried out at different ages (from birth to maturity) which is a critical period in the development of the uterus to see how age affects both gonadotropin receptors expression and at different reproductive statuses (pregnancy) to know how far pregnancy can affect the expression of gonadotropin receptors.
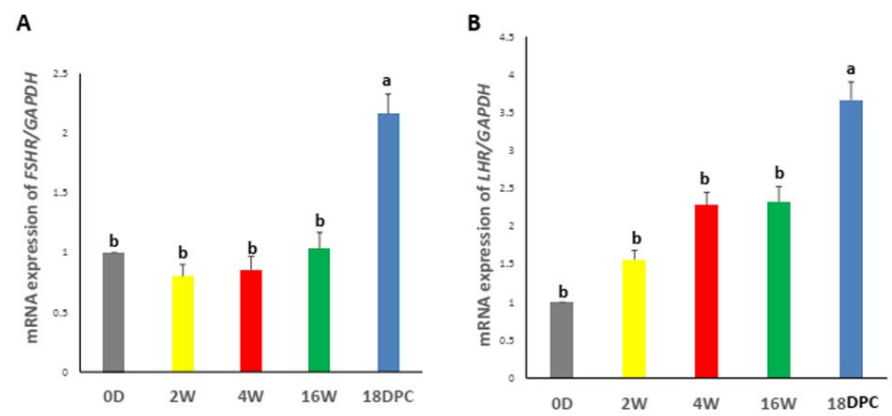

Figure 2: Assessment of mRNA Levels by RT-PCR during the development of rabbit uterus. (A) Relative expression of mRNA levels for FSHR (B) Relative expression of mRNA levels for LHR. The different letters above the bars reflect the significant differences between the different uterine developmental stages $(P<0.05)$. Data presented in form of mean \pm SEM. Abbreviations: FSHR, Follicular stimulating hormone receptor; $L H R$, Luteinizing hormone receptor; 0D, 0 day; 2W, 2 Weeks; 4W, 4 Weeks; 16W, 16 Weeks; 18dpc, 18day post-coitum.

A

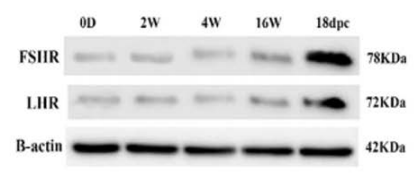

B
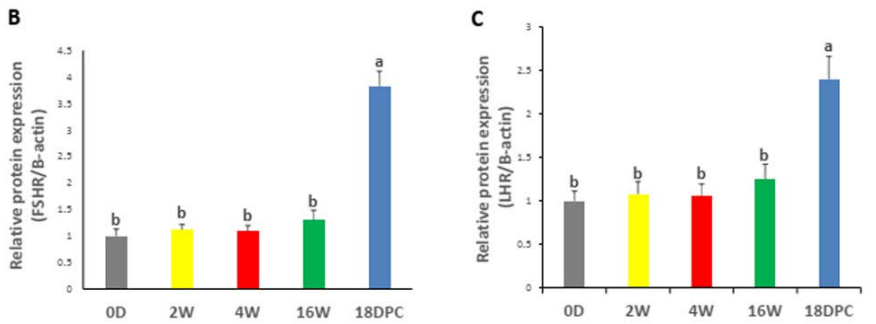

Figure 3: Uterine FSHR and LHR Protein Levels by using western blot (A) Immunodetection of FSHR and LHR and $\beta$-actin (control) at different ages. (B) FSHR/ $\beta$-actin densitometrical assessment (C) LHR/ $\beta$-actin densitometrical assessment. The different letters above the bars reflect the significant differences between the different uterine developmental stages $(\mathrm{P}<0.05)$. Data presented in form of mean \pm SEM. Abbreviations: FSHR, Follicular stimulating hormone receptor; LHR, Luteinizing hormone receptor; 0D, 0 day; 2W, 2 Weeks; 4W, 4 Weeks; 16W, 16 Weeks; 18dpc, 18 day post-coitum.
Histologically, the uterus of newly born rabbit (D 0 ) had not been differentiated into its definite three layers, instead, it mainly consisted of undifferentiated mesenchyme surrounds a simple epithelium and without uterine glands. Similar developmental status was reported by Abiaezute et al. (2017). Within 2 weeks after birth, the uterus differentiated into three layers with appearance of primordium of uterine glands. The same result was described by Hayashi and Spencer (2005) and Bukar et al. (2006). By week 4, the number of glandular primordia increased and became gradually canalized acquiring a simple tubular appearance as descripted by Taylor et al. (2000) and Hayashi et al. (2004). By reaching week16, the uterus developed further involved branching and coiling of endometrial glands within the lamina propria-submucosa. The same pattern was obtained by Taylor et al. (2000) and Carpenter et al. (2003).

The present study showed that no significant changes were observed in the expression levels of mRNA and protein of FSHR and LHR from birth to week 16, although there were significant uterine developmental changes in the time interval between birth and maturity, such as the uterine gland's appearance and proliferation, endometrial fold development, and myometrial layer growth. It is apparent from these findings that both gonadotropin receptors' expression appeared to be independent of the age of rabbits as the expression of these receptors in the uterus did not increase with the linear developmental changes in the rabbit uterus. In other words, the uterine expression of gonadotropin receptors is not compatible with histological assays.

Gonadotropin receptors may not be implicated in regulating the postnatal rabbit uterine development. So, we postulated that uterine development may be affected by other factors. Effects of growth factors on mouse uterus development were shown in previous studies (Hu et al., 2004). Previous studies have shown that the insulin-like growth factor (IGFs), hepatocyte growth factor, and fibroblast growth factor play essential roles in ovine uterus postnatal development (Taylor et al., 2001; Hayashi et al., 2005). Estrogen receptors (ESR1, ESR2) and progesterone receptors (PR) are necessary to uterine growth and development, stimulation and maintenance of endometrial gland genesis, and branching morphogenesis (Taylor et al., 2000; Meikle et al., 2004).

Notably, the mRNA and protein levels of both gonadotropin receptors increased significantly during pregnancy. This finding indicates that the gonadotropin receptors expression seemed to be affected by reproductive status (pregnancy), suggesting a potential role of gonadotropin receptors in the rabbit uterus during pregnancy. Although there is little clarity in the function of both uterine gonadotropin 
receptors and its physiological function is still explained in the uterus. Researchers have hypothesized that uterine LHR's main function is to promote growth and hyperplasia, maintain uterine relaxation during pregnancy, and increase blood flow during pregnancy in the uterine artery (Lei et al., 1992; Ziecik et al., 2001). FSHR may play an integral role in regulating the myometrial contractile activity that was required for pregnancy maintenance (Stilley et al., 2014).

In general, the current findings do not support a role of FSHR/LHR as a regulator of rabbit uterine development. However, there is a limitation in this study in terms of FSHR /LHR knockout studies, which will no doubt contribute to our understanding of the role of extragonadal FSHR/LHR. Future studies are necessary to validate our current findings.

\section{CONCLUSIONS AND RECOMMENDATIONS}

Expression of FSHR and LHR did not show any significant difference from birth to maturity and this is not consistent with the specific histologic features of the rabbit uterus during the developmental stages, suggesting that these receptors are not implicated in regulating rabbit uterine development and that uterine development is controlled by factors other than FSHR and LHR. However, at pregnancy, their expression significantly increased indicating a possible vital-role of both gonadotropin receptors during pregnancy in the rabbit uterus.

\section{ACKNOWLEDGMENTS}

The authors wish to express their gratitude to Faculty of Veterinary Medicine/ Benha University for supporting this work.

\section{NOVELTY STATEMENT}

This study is the first to relate changes in FSHR and LHR expression at the mRNA and protein levels to uterine histological changes in female rabbits using RT-PCR, western blot, and histological techniques.

\section{AUTHOR'S CONTRIBUION}

MM, HB, AK \& AE: Idea and design. EK: Tissue samples collection and lab analysis. Ek \&AE: Write the manuscript. MM, HB\& AK: Revision.

\section{CONFLICT OF INTEREST}

The authors have declared no conflict of interest.

\section{REFERENCES}

-Abd-Allah SH, Shalaby SM,Abd-Elbary E, Saleh AA, El-Magd MA (2015). Human peripheral blood CD34+ cells attenuate oleic acid induced acute lung injury in rats. Cytotherapy, 17: 443-453. https://doi.org/10.1016/j.jcyt.2014.11.002

-Abd-Elkareem MD (2017). Morphological, histological and immunohistochemical study of the rabbit uterus during pseudopregnancy. J. Cytol. Histol., 8(1): 1-7.

- Abiaezute CN, Nwaogu IC and Okoye CN (2017). Morphological features of the uterus during postnatal development in the West African Dwarf goat (Capra hircus). Anim. Reprod., 14: 1062-1071. https://doi. org/10.21451/1984-3143-AR886

-Ascoli M, Fanelli F, Segaloff DL (2002). The lutropin/ choriogonadotropin receptor, a 2002 perspective. Endocr. Rev., 23: 141-174. https://doi.org/10.1210/edrv.23.2.0462

- Bukar MM, Amin JD, Sivachelvan MN, Ribadu AY (2006). Postnatal histological development of the ovaries and uterus and the attainment of puberty in female kid goats. Small Rumin. Res., 65: 200-208. https://doi.org/10.1016/j. smallrumres.2005.06.019

- Carpenter KD, Gray CA, Bryan TM, Welsh TH, Spencer TE (2003). Estrogen and antiestrogen effects on neonatal ovine uterine development. Biol. Reprod., 69: 708-717. https:// doi.org/10.1095/biolreprod.103.015990

- Costagliola S, Urizar E, Mendive F, Vassart G (2005). Specificity and promiscuity of gonadotropin receptors. Reproduction, 130: 275-281. https://doi.org/10.1530/rep.1.00662

-Dias JA, Cohen BD, Lindau-Shepard B, Nechamen CA, Peterson AJ, Schmidt A (2002). Molecular, structural, and cellular biology of follitropin and follitropin receptor. Vitam. Horm., 64: 249-322. https://doi.org/10.1016/S00836729(02)64008-7

- Feldman AT, Wolfe D (2014). Tissue processing and hematoxylin and eosin staining. Histopathology, Springer, pp. 31-43. https://doi.org/10.1007/978-1-4939-1050-2_3

- Gray CA, Bartol FF, Tarleton BJ, Wiley AA, Johnson GA, Bazer FW, Spencer TE (2001). Developmental biology of uterine glands. Biol. Reprod., 65: 1311-1323. https://doi. org/10.1006/dbio.2001.0381

- Hayashi K, Carpenter KD, Spencer TE (2004). Neonatal estrogen exposure disrupts uterine development in the postnatal sheep. Endocrinology, 145: 3247-3257. https:// doi.org/10.1210/en.2004-0178

- Hayashi K, Carpenter KD, Welsh TH, Burghardt RC, Spicer LJ, Spencer TE (2005). The IGF system in the neonatal ovine uterus. Reproduction, 129: 337-347. https://doi. org/10.1530/rep.1.00342

-Hayashi K, Spencer TE (2005). Estrogen disruption of neonatal ovine uterine development: effects on gene expression assessed by suppression subtraction hybridization. Biol. Reprod., 73: 752-760. https://doi.org/10.1095/biolreprod.105.042812

- Hu J, Gray CA, Spencer TE (2004). Gene expression profiling of neonatal mouse uterine development. Biol. Reprod., 70: 1870-1876. https://doi.org/10.1095/biolreprod.103.026336

- Lei ZM, Reshef E, Rao V (1992). The expression of human chorionic gonadotropin/luteinizing hormone receptors in human endometrial and myometrial blood vessels. J. Clin. Endocrinol. Metab., 75: 651-659. https://doi.org/10.1210/ jcem.75.2.1379262

-Liang H, Chen L, Liu Z, Zhou X (2012). Expression of functional follicle-stimulating hormone receptor and 
luteinizing hormone/chorionic gonadotrophin receptor in oviduct and uterus in prepubertal gilts. Livest. Sci., 148: 74-80. https://doi.org/10.1016/j.livsci.2012.05.012

-Livak KJ, Schmittgen TD (2001). Analysis of relative gene expression data using real-time quantitative PCR and the 2- $\Delta \Delta \mathrm{CT}$ method. Methods, 25: 402-408. https://doi. org/10.1006/meth.2001.1262

- Meikle A, Tasende C, Sosa C, Garófalo EG (2004). The role of sex steroid receptors in sheep female reproductive physiology. Reprod. Fertil. Dev., 16: 385-394. https://doi.org/10.1071/ RD04036

-Mukherjee D, Kundu S and Pramanick K (2010). Gonadotropin receptors in uterus, their distribution and functional gonadal functions.

- Narayan P, Ulloa-Aguirre A, Dias JA (2018). Gonadotropin hormones and their receptors, eighth edi. Yen Jaffe's Reprod Endocrinol Physiol Pathophysiol Clin Manag Eighth Ed. https://doi.org/10.1016/B978-0-323-47912-7.00002-0

- Sacchi S, Sena P, Degli Esposti C, Lui J, La Marca A (2018). Evidence for expression and functionality of FSH and LH/ hCG receptors in human endometrium. J. Assist. Reprod. Genet., 35: 1703-1712. https://doi.org/10.1007/s10815018-1248-8

- Sawitzke AL, Odell WD (1991). Uterine binding sites for LH/hCG can be modulated by hormonal status in rabbits and rats. Eur. J. Endocrino., 1 (124): 322-330. https://doi. org/10.1530/acta.0.1240322

- Spencer TE, Hayashi K, Hu J, Carpenter KD (2005). Comparative developmental biology of the mammalian uterus. Curr. Top. Dev. Biol., 68: 85-122. https://doi. org/10.1016/S0070-2153(05)68004-0

- Stilley JAW, Christensen DE, Dahlem KB, Guan R, Santillan DA, England SK, Al-Hendy A, Kirby PA, Segaloff DL (2014). FSH receptor (FSHR) expression in human extragonadal reproductive tissues and the developing placenta, and the impact of its deletion on pregnancy in mice. Biol. Reprod., 91: 71-74. https://doi.org/10.1095/ biolreprod.114.118562

- Taylor KM, Chen C, Gray CA, Bazer FW and Spencer TE (2001). Expression of messenger ribonucleic acids for fibroblast growth factors 7 and 10, hepatocyte growth factor, and insulin-like growth factors and their receptors in the neonatal ovine uterus. Biol. Reprod., 64: 1236-1246. https:// doi.org/10.1095/biolreprod64.4.1236

-Taylor KM, Gray CA, Joyce MM, Stewart MD, Bazer FW and Spencer TE (2000). Neonatal ovine uterine development involves alterations in expression of receptors for estrogen, progesterone, and prolactin. Biol. Reprod., 63: 1192-1204. https://doi.org/10.1095/biolreprod63.4.1192

-Wang LH, Zhang W, Gao QX, Wang F (2012). Expression of the luteinizing hormone receptor (LHR) gene in ovine nongonadal tissues during estrous cycle. Genet. Mol. Res., 11: 3766-3780. https://doi.org/10.4238/2012.October.15.8

-Wei S, Guo H, Gong Z, Zhang F, Ma Z (2016). Triptorelin and cetrorelix induce immune responses and affect uterine development and expressions of genes and proteins of ESR1, LHR, and FSHR of mice. Immunopharmacol. Immunotoxicol., 38: 197-204. https://doi.org/10.3109/089 23973.2016.1168432

- Yang P, Wang J, Shen Y, Roy SK (2004). Developmental expression of estrogen receptor (ER) $\alpha$ and ER $\beta$ in the hamster ovary: regulation by follicle-stimulating hormone. Endocrinology, 145: 5757-5766. https://doi.org/10.1210/ en.2004-0779

-Zheng M, Shi H, Segaloff DL, Van Voorhis BJ (2001). Expression and localization of luteinizing hormone receptor in the female mouse reproductive tract. Biol. Reprod., 64: 179-187. https://doi.org/10.1093/biolreprod/64.1.179

-Ziecik AJ, Derecka K, Gawronska B, Stepien A, Bodek G (2001). Nongonadal LH/hCG receptors in pig: Functional importance and parallels to human. Semin. Reprod. Med., 19: 19-30. https://doi.org/10.1055/s-2001-13907 